\title{
Las concepciones monárquicas de los intelectuales conversos en la Castilla del siglo $\mathrm{xV}$
}

\author{
José Manuel Nieto Soria*
}

\section{EL SIGLO XV CASTELLANO COMO ÉPOCA DE PREOCUPACIÓN POR LA DEFINICIÓN DE LOS IDEALES MONÁRQUICOS}

El conjunto del siglo $x v$ representa para el reino de Castilla un momento de gran actividad en lo que se refiere a la elaboración de productos intelectuales de muy diversa índole en los que, bien de forma directa, bien de forma indirecta, la reflexión sobre el significado de la realeza y del poder monárquico se convierten en argumentos destacados de primer orden.

Los intelectuales de la época fueron conscientes de que se hallaban inmersos en un proceso complejo, pero muy dinámico, que si la historiografía actual ha intentado hacerlo inteligible a partir de la utilización del término de "génesis del Estado Moderno" ", para ellos, presentaba como uno de sus rasgos más definitorios las aspiraciones de la institución monárquica de conseguir unas pretensiones de poder que, de una manera muy simplificada, se resumirían en unos objetivos de mayor centralismo en los procedimientos administrativos y en el tratamiento de las decisiones políticas, lo que habría de traducirse en la afirmación de una cierta forma de autoritarismo regio que habría de presentar, necesariamente, fórmulas diversas según las tradiciones jurídico-políticas de cada reino.

Universidad Complutense. Madrid.

Véase una visión de conjunto para los reinos hispánicos de lo que significó globalmente esta génesis del Estado moderno en LADERO QUESADA, Miguel Ángel, «La genèse de l'Etat dans les royaumes hispaniques médiévaux (1250-1450)", Le premier âge de l'Etat en Espagne (14501700), coord. Christian Hermann. París 1989, págs. 9-65. 
Si cualquier intelectual de aquel entonces podía disponer ya de un importante número de textos, tanto de la centuria anterior, como de su propio siglo, en los que podía encontrar un buen número de reflexiones, en las que se ponía de relieve unas tendencias autoritarias, de las que se podían encontrar amplias argumentaciones orgánicas ${ }^{2}$, le bastaba con leer cualquier documento emanado de la Cancillería real para encontrar abundantes expresiones formularias, tales como «poderío real absoluto", bien expresivas de esas nuevas pretensiones de poder que aspiraban a convertirse en realidades. Del mismo modo, también era posible tomar contacto con ese hecho incuestionable a través de las cada vez más frecuentes ceremonias políticas, en los que se ponía de manifesto una clara y perceptible imagen del poder regio que lo situaba en una posición de superioridad incomparable ${ }^{3}$.

En consecuencia, para cualquier intelectual medianamente observador, resultaba imposible sustraerse a esta realidad política que, inevitablemente, debía tener algún tipo de reflejo en la obra escrita.

Por ello, a lo largo de todo el conjunto del siglo xv, es posible encontrar una notable riqueza de imágenes de la realeza y del poder regio, bien representativas de esa nueva configuración autoritaria que éste va tomando. Tales imágenes se pueden advertir en obras de muy diversa índole. Así sucede, por ejemplo, en la abundante producción historiográfica de la época. Tanto en la cronística, como en obras que superan los propios planteamientos cronísticos para ofrecer una perspectiva propia de la historia universal, es posible encontrar representaciones bien tangibles de los ideales monárquicos vigentes. También se da tal circunstancia en la producción literaria, unas veces a través de la utilización de recursos alegóricos ${ }^{4} \mathrm{u}$ otras mediante referencias apologéticas, tal como es frecuente en los cancioneros ${ }^{5}$. Las colecciones epistolares suelen ser también ricas en este tipo de consideraciones ${ }^{6}$. $Y$ ya no digamos los nu-

\footnotetext{
2 Véase a este respecto MARAVAL!-, José Antonio, Estado moderno y mentalidad social (siglos XV a XVII), 2. ${ }^{a}$ ed. I. Madrid 1986, págs. 249-311.

3 Sobre esta cuestión puede verse nuestra monografía: Ceremonias de la realiza. Propaganda y legitimación en la Castilla trastamara, Madrid, 1993.

${ }^{4}$ Un buen ejemplo de estos recursos alegóricos de intencionalidad política a través de los que se ofrece una cierta imagen de la realeza puede encontrarse en PALENCIA, Alfonso de, Batalla campal de los lobos y perros, ed. de Antonio M. Fabié. Madrid 1876.

5 Sobre la imagen de la realeza en los cancioneros del siglo xV y su valor propagandístico puede verse NiETo SORIA, José Manuel, «Apología y propaganda de la realeza en los cancioneros castellanos del siglo xv. Diseño literario de un modelo político", en La España Medieval, n. ${ }^{\circ} 11,1988$, págs. 185-222.

6 Así sucede, por ejemplo, con las de Fernando del Pulgar, Fernán Gómez de Cibdadreal - Pedro Mártir de Anglería, entre otros.
} 
merosísimos tratados de teoría política aparecidos durante esta centuria, cuya propia abundancia ya nos habla de la preocupación por este tipo de temas ${ }^{7}$.

Es un aspecto llamativo en estos textos el absoluto predominio que se puede encontrar en ellos de posturas en las que los autores nunca cuestionan la utilización que hacen los monarcas del poder ${ }^{8}$, haciéndose más hincapié en aquellas referencias teóricas, de orden tanto teológico como jurídico, que contribuyen a poner de relieve la falta de limitación del poder regio ${ }^{9}$, que en aquellas otras a partir de las cuales se podía justificar algúna fórmula delimitadora ${ }^{10}$.

Desde este punto de vista, es indudable que la época de los Reyes Católicos presenta un material particularmente abundante y bien caracterizado en cuanto a sus contenidos concretos. Sin embargo, ya desde tiempos de Juan II se puede constatar la presencia de frecuentes imágenes autoritarias de la realeza en los escritos de los intelectuales de la época, si bien es posible advertir que si con este monarca suelen predominar las simples expresiones apologéticas o de exaltación, con los Reyes Católicos resulta más factible encontrar enunciaciones orgánicas más completas de cómo se entiende el poder regio desde una perspectiva autoritaria ${ }^{11}$.

Una parte muy importante de los escritos, de cualquier índole que sean, en los que se recoge alguna forma de concepción del poder regio

7 Una relación detallada de los tratados de teoría política aparecidos, en concreto, durante la época de los Reyes Católicos puede encontrarse en LADERo QUESADA, Miguel Ángel, Los Reyes Católicos: la Corona y la unidad de España. Valencia 1989, págs. 75-86.

8 Así lo ha puesto recientemente de manifiesto Ottavio di Camillo: "A juzgar por lo que se escribía en esta época aparece que los autores de los textos literarios que nos han llegado nunca cuestionaron el uso que los reyes hacían del poder." Camillo, Ottavio di, "¿Existe una literatura de oposición enl a España de fines de la Edad Media?, en Genèse médiévale de l'Espagne moderne. Du refus à la révolte: les resistances, dir. A. Rucquoi. Niza 1991, pág. 168.

9 Véase a este respecto NiETo SoRIA, José Manuel, Fundamentos ideológicos del poder real en Castilla (siglos XIII-XVI) . Madrid 1988.

10 En este mismo sentido se ha manifestado con toda claridad Alan Deyermond: «El estado moderno de los Reyes Católicos, y el imperio que está a punto de nacer, tienen su ideología no sólo en tratados teóricos, no sólo en las crónicas, sino también, y de manera muy reveladora, en la literatura en el sentido más estricto -la poesía, la ficción en prosa-.. DEYERMOND, Alan, "La ideología del estado moderno en la literatura española del siglo XV", Realidad e imágenes del poder. España a fines de la Edad Media. Valladolid 1988, pág. 192.

i1 En este punto cabe advertir una cierta correspondencia con lo que sucede en el plano de las ceremonias políticas de la realeza, donde también se pasa de una época de gran multiplicación de las ceremonias de exaltación del poder regio, con Juan II, a otra en la que éstas. sin ser tan abundantes, ofrecen una imagen más completa y estructurada de valor propagandístico del concepto de poder regio que se pretende comunicar a efectos de propaganda y legitimación. 
son obra de autores conversos. Incluso se podría afirmar que sabríamos muy poco de la imagen intelectual, que se tiene del poder regio en la Castilla del siglo $\mathrm{xv}$, si no tuviéramos conocimiento de las páginas salidas de la pluma de estos autores conversos. Este es un hecho incuestionable.

La constatación de tal circunstancia hace que vuelva a tomar de nuevo vigencia la polémica que en su día mantuvieran Américo Castro y Eugenio Asensio sobre la supuesta "peculiaridad literaria" de los conversos, ahora aplicada al ámbito concreto de la literatura de contenido político ${ }^{12}$.

Frente a la opinión de Américo Castro, Eugenio Asensio negaba el que los conversos pudieran ser considerados como un grupo con una sensibilidad literaria propia y definida, rechazando la existencia de «uniformidad ni en la visión del mundo, ni en la expresión literaria de los neocristianos» ${ }^{13}$. Negando cualquier posibilidad de establecer "rasgos distintivos comunes denotadores de "casta"» ${ }^{14}$. De este modo se rechazaba la argumentación principal de Américo Castro, por la que se pretendía establecer la presencia de «una mentalidad y una sensibilidad distintiva de los conversos" ${ }^{15}$.

Aceptada la tesis de Eugenio Asensio, al constatar ahora el importante relieve de las obras de los conversos castellanos del siglo xv desde la perspectiva específica de la presentación de una imagen de la realeza, no queda más remedio que volver a plantearse la pregunta que dio lugar a aquella polémica, pero para el asunto concreto que ahora nos interesa, el de la imagen de la realeza: ¿existió una sensibilidad distintiva y característica hacia la concepción del poder regio entre los intelectuales conversos en la Castilla del siglo XV? El análisis a desarrollar habrá de encaminarse necesariamente a tratar de dar una respuesta lo más precisa posible a tal problema.

Dicho análisis habrá de fundamentarse preferentemente en la consideración, lo más sistemática posible de lo que fueron las imágenes de la realeza plasmadas en los escritos, de muy diversa índole, de algunos de los intelectuales conversos más relevantes de la época, sin que se pretenda desarrollar un estudio totalizador de todos los autores posibles que, evidentemente, excedería con mucho de los límites de este trabajo.

\footnotetext{
12 Para el estudio de dicha polémica puede verse el artículo de AsEnSIO, Eugenio, «La peculiaridad literaria de los conversos", Anuario de Estudios Medievales, n. 4, 1967, págs. 328 351.

13 Ibidem, pág. 329.

14 Ibidem, pág. 330.

15 lbidem, pág. 338.
} 
En el caso concreto de los autores considerados, tampoco habrá de pretenderse realizar una valoración de todas y cada una de las imágenes de la realeza constatables, sino, tan sólo de aquéllas que se han entendido, desde mi propia subjetividad, como más características o significativas en el contexto de la obra de cada autor.

Finalmente, no todos los autores pueden ser estudiados en pie de igualdad. Ciertamente, no en todos los casos la reflexión sobre la realeza y el poder real ocupa un relieve equiparable, ni tiene el mismo significado en la plasmación sintomática de una cierta ideología del poder regio en la Castilla del siglo XV. Es así que se han establecido tres grupos distintos.

El primero de estos grupos es el formado por dos autores conversos que se han considerado en este análisis como principales, en cuanto que es posible apreciar en ellos una auténtica fijación por lo que es la imagen del poder regio y cuyas opiniones pueden considerarse como muy representativas de las que fueron predominantes en este punto a fines del medievo. Tales autores serán Fernando del Pulgar y Diego de Valera. Característica esencial de estos autores será el que es posible advertir en ellos una auténtica voluntad definidora de un determinado concepto del poder regio, siendo esta consciencia conceptualizante, una dimensión esencial a la hora de valorar su significación desde el punto de vista que aquí interesa prioritariamente. En ambos casos se puede apreciar un intento de reflexión, a veces casi erudita, sobre este tipo de cuestiones. Pero, además, la selección de estos autores como principales ha sido consecuencia de entender que su aproximación intelectual a la concepción de un modelo monárquico puede tener mucho de simbólico, para lo que pudieron ser unas actitudes predominantes, también dentro del grupo de los conversos más ilustrados.

Otro grupo de autores ha sido considerado, con relación al anterior, como de valor secundario, en cuanto que la enunciación que hacen de su percepción del poder regio supone un esfuerzo subsidiario con respecto a su afán fundamental para conseguir una expresión literaria lo más elevada posible. Frente a esa reflexión erudita, a la que se hacía referencia, para los que se han elegido como autores principales, entre éstos se pueden encontrar, en cambio, expresiones de exaltación y de manifestaciones apologéticas, siendo la composición poética el procedimiento más habitualmente empleado para conseguir ese objetivo. En este grupo se podría incluir a un buen número de los poetas de cancioneros, tan abundantes en la Castilla del siglo $\mathrm{xv}$, entre los que es posible hallar un abultado grupo de conversos: fray Diego de Valencia, Juan Alfonso de Baena, Gonzalo Martínez de Medina, fray Íñigo de Mendoza, Antón de Montoro, Juan Álvarez Gato... A ellos también se puede añadir algún otro 
escritor, que, si bien ajeno a la expresión versificada, incluye alguna forma de alusión a su percepción del poder regio, tal como es el caso de un Juan de Lucena.

Finalmente, no se puede soslayar la consideración de algunos autores, que en su momento, habré de valorarlos como fuente esencial de referencia para algunas de las concepciones monárquicas expresadas por los intelectuales conversos seleccionados. Éste es el caso de Pablo de Santa María, Alfonso de Cartagena y Alvar García de Santa María.

Será a partir de la valoración de la percepción, que del poder regio manifiestan en sus obras estos tres grupos de autores, cómo se podrá dar respuesta a la pregunta antes planteada, referida a la posibilidad de una sensibilidad política específica de los intelectuales conversos en la Castilla del siglo XV.

\section{PULGAR Y VALERA: DOS CONVERSOS CON UNA SENSIBILIDAD POLITICA DIFERENCIADA}

La elección de Fernando del Pulgar y de Diego de Valera, como los que se han denominado autores principales, ha sido el resultado de entender que su obra representa una manifestación bien palpable de un decidido y consciente intento de plasmar la concepción individual que en cada caso se tuvo de lo que se entendía como realeza. Siendo su resultado una construcción en perfecta consonancia con lo que eran las tendencias autoritarias del momento, resultando casi imposible establecer la visión intelectual de la realeza castellana a fines del medievo sin tener en cuenta sus aportaciones en esta materia.

Sin embargo, cuando se emprende un análisis sistemático de sus opiniones políticas sobre el origen, función y significado del poder regio llama la atención comprobar que nos hallamos ante dos planteamientos radicalmente diferentes. En efecto, se trata de dos percepciones de la realeza y dos sensibilidades políticas que se mueven en dimensiones completamente distintas, aunque no falte un núcleo común coincidente en lo esencial.

Si en el caso de Pulgar estamos ante lo que podría entenderse como una percepción religiosa de la realeza; en Valera nos hallamos ante una percepción esencialmente jurídico-política, funcional y cortesana de la misma, tratándose, por tanto, de planteamientos complementarios que revelan las dos facetas esenciales de las concepciones monárquicas de la época, de forma que, sólo mediante la unión de ambos, es posible acercarse a lo que sería una imagen casi completa de cómo solía entenderse el poder 
regio en una aproximación teórica a fines del medievo. Por otro lado, ya a partir de esta diversidad de planteamientos, apreciable en estos dos autores, cabe establecer un primer indicio de la dificultad que conlleva pretender encontrar en los intelectuales conversos del siglo XV un grupo homogéneo en sus planteamientos en el campo de las concepciones políticas referidas a la realeza.

La "percepción religiosa" de la realeza, exhibida por Fernando del Pulgar, se asienta en la caracterización del monarca a partir de una cuádruple óptica. El monarca es un ungido de Dios, posee una inspiración divina y es un rey mesías y un rey cristianísimo.

Para Pulgar parece que todo rey castellano, por el hecho de serlo, a pesar de cuál sea su trayectoria política individual, debe ser considerado como un rey ungido, carácter que nada tiene que ver con que se haya producido el acto ceremonial de la unción ${ }^{16}$. Son precisamente sus glosas a las Coplas de Mingo Revulgo uno de los textos donde Pulgar utilizará más reiteradamente esta expresión de «rey ungido» para aplicarla a Enrique IV en sus horas más bajas ${ }^{17}$ y hacia el que nuestro autor siempre mantuvo una lealtad inquebrantable ${ }^{18}$. En este punto hay que señalar cómo Fernando del Pulgar guardaba estrechas relaciones con el por entonces obispo de Calahorra, don Pedro González de Mendoza, también decidido sostenedor de la causa regia frente a los partidarios del infante don Alfonso, haciendo también el prelado referencia al monarca como rey ungido ${ }^{19}$, del mismo modo que sucedería en el caso del cronista regio Diego Enríquez del Castillo ${ }^{20}$. Así, por tanto, da la impresión que la uti-

16 Esta consideración solía avalarse a partir de la alusión a textos bíblicos veterotestamentarios en los que el rey Salomón actuaba como referente más habitual. Esta misma circunstancia también es constatable para el caso de Fernando del Pulgar, tal como se puede comprobar a partir del fragmento recogido en la nota siguiente.

17 «Y porque los reyes, según se lee en la Sagrada Escritura, en otro tiempo eran ungidos con aceite santo, quiere decir que como quier que es rey natural y ungido, según razón debería curar la roña, conviene saber, castigar los vicios y pecados del pueblo (...) Así que esta copla quiere decir que como quiere que su gobernador es rey natural y ungido, no cura de lo que se requiere a la buena gobernación del pueblo, según que buen rey debe hacer». PULGAR, Fernando del, Glosa a las Coplas de Mingo Revulgo, ed. J. Domínguez Bordona, glosa a la copla VIII. Madrid 1958, págs. 168-169.

18 Fernando del Pulgar era en 1458 secretario real de Enrique IV, obteniendo diversas mercedes del monarca, del que actuó como embajador en algunas ocasiones. No hay duda sobre la lealtad de Fernando del Pulgar hacia el rey durante la sublevación nobiliaria, ordenándose por el príncipe Alfonso la confiscación de sus bienes a fin de que sean entregados a su secretario Fernando de Arce. Esta lealtad hacia Enrique IV no fue obstáculo para que fuera un servidor fiel de los Reyes Católicos cuando éstos llegaran al trono. Véase Rábade Obradó, María del Pilar, Los judeoconversos en la corte y en la época de los Reyes Católicos. Madrid 1990, págs. 603-604.

19 Memorial Histórico Español, vol. VI, pág. 171

20 Enpíquez del Castillo, Diego, Crónica de Enrique N. Madrid 1953, págs. 144. Véase 
lización de tales términos, aparte de que pudiera suponer el reflejo de una convicción personal, también era reflejo de una estrategia propagandística sostenida por aquellos que formaron parte del entorno regio en los días difíciles para el rey castellano que habían de suceder a la Farsa de Ávila.

La consideración de reyes inspirados por Dios será utilizada por Pulgar para aplicarla específicamente a los Reyes Católicos. En efecto, la reina Isabel es aludida repetidamente por Pulgar a lo largo de su crónica de estos monarcas como un ejemplo de inspiración divina ${ }^{21}$. La cronística avalaba la alusión a este tipo de referencias a partir de la utilización como base textual de diversos fragmentos del Antiguo Testamento ${ }^{22}$. Sin embargo, este tipo de planteamientos no representaba una característica exclusiva de Pulgar, pues, por el contrario, algunos panegiristas coetáneos de los Reyes Católicos emplearon este mismo recurso, tal como puede comprobarse, entre otros, en un Pedro Mártir de Anglería ${ }^{23}$ o en un Lucio Marineo Sículo ${ }^{24}$.

Los planteamientos mesiánicos empleados por Fernando del Pulgar para describir lo. que considera como una de las facetas esenciales de su ideal monárquico aparecen en sus escritos a cada paso aplicados a los Reyes Católicos ${ }^{25}$. El propio príncipe don Juan, con motivo de su nacimiento, será utilizado como sujeto de un decidido enfoque mesiáni$\mathrm{co}^{26}$. Uno de los contenidos esenciales de tal planteamiento mesiánico

también Bermejo Cabrero, José Luis, "Las ideas políticas de Enríquez del Castillo", Revista de la Universidad Complutense de Madrid, n. ${ }^{\circ} 86,1973$, pág. 73.

21 «E aquí pareció claro como esta Reyna era movida á las cosas por alguna inspiración dividna, porque como quier que era humana é tambien ella como todas las gentes le deseaban fablar, pero fué como cosa maravillosa que en aquella hora la Reyna, tocada de algún espíritu divino...»P Pulgar, Fernando del, Crónica de los Reyes Católicos, III parte, capítulo LXXXVII. Madrid 1953, pág. 466

22 En efecto, se puede encontrar una transcripción directa de textos veterotestamentos alusiva a la condición de reyes inspirados de Dios, sobre todo, en diversos fragmentos de la Crónica latina de los reyes de Castilla, tales fragmentos proceden preferentemente de los libros de Samuel, del Eclesiastés, los Salmos y de los Jueces.

${ }^{23}$ Mártir de Anglería, Pedro, Epistolario, ed. de José López de Toro, epíst. 3 (27-II-1488). Madrid 1953.

24 Marineo Sículo, Lucio, Vida y hechos de los Reyes Católicos. Madrid 1943, pág. 75.

25 Estos planteamientos mesiánicos tendrán como una de las fórmulas más habituales de expresión hacer referencia al radical cambio acontecido en el reino al trocarse las turbaciones en un estado de plena justicia como consecuencia de la acción regia, constituyendo tal proceso de transformación una manifestación tangible del significado de los monarcas como mesías o enviados por Dios para imponer la paz y la concordia en el reino. Un buen ejemplo de esta óptica puede encontrarse en PULGAR, Fernando del, Letras, ed. de J. Domínguez Bordona, letra XI. Madrid 1958, págs. 53-55

26 Ibidem, letra IX, págs. 49-50 
será la creencia en una permanente protección divina hacia los morlarcas que asegura el éxito de sus empresas ${ }^{27}$.

Consecuencia de todas las anteriores consideraciones es que Fernando del Pulgar presenta a sus monarcas como reyes católicos ejemplares, lo que contribuye a asegurar la mayor bondad de todos los súbditos y, por ende, el bienestar de todo el reino ${ }^{28}$. Con tal apreciación se sitúa en la misma línea de un buen número de escritos políticos castellanos que, desde el siglo xIII, venían señalando la importancia esencial que tenía para la estabilidad política del reino la dimensión de los monarcas como reyes cristianísimos $^{29}$.

Así, pues, el predominio de un enfoque de la realeza de índole religiosa, en el que los contenidos mesiánicos, proféticos y providencialistas ocupan un lugar central, constituyen aspectos fundamentales en la caracterización del concepto de monarquía exhibido por Fernando del Pulgar. Esta circunstancia ha llevado a pensar a algún autor que todo ello es una manifestación de su origen judío ${ }^{30}$. Sin embargo, ¿cuántos autores coetáneos de Pulgar, sin tener ninguna referencia judaica en sus trayectorias vitales, también presentaron esta misma óptica? Es indudable que, buena parte de los escritores de narraciones históricas de la época en que le tocó vivir a Pulgar coincidieron en estos mismos planteamientos que representaron una línea de pensamiento muy generalizada, a la vez que poseedora de una gran fuerza literaria, comprensible en un contexto mental que algún autor, a mi modo de ver acertadamente, ha calificado como de mesiánico ${ }^{31}$.

Buena muestra de cómo dos conversos coetáneos ensayan una representación intelectual de la monarquía a partir de planteamientos bien distintos se puede obtener a partir de la comparación de lo que se acaba

27 Véase, por ejemplo, la alusión a esta protección divina, esta vez referida específicamente a Fernando el Católico, en PuLgaR, Fernando del, Claros varones de Castilla, ed. de J. Domínguez Bordona, t. I. Madrid 1969, pág. 13.

28 PuLGaR, Fernando del, Letras, letra XXXII, págs. 139-140.

29 Véase a este respecto NIETO SORIA, José Manuel, Fundamentos ideológicos del poder real en Castilla, págs. 79-84.

${ }_{30}$ Así lo señala José Cepeda Adán: «En su estilo y, sobre todo, en su mesianismo aparece clara esta huella de su origen. Pulgar, cristiano nuevo, aunque de la más limpia ortodoxia, está empapado de hebraísmo en sus juicios históricos. No concibe la Historia sin una intervención decidida y final de Dios. Sus palabras tienen a veces acento bíblico y resuenan como una voz profética». CEPEDA ADÁN, José, "El providencialismo en los cronistas de los Reyes Católicos", Arbor, n. ${ }^{\circ}$ XVII, 1950, págs. $179-80$.

1 Sobre este contexto mesiánico puede verse MILHOU, Alain, Colón y su mentalidad mesiánica en el ambiente franciscanista español. Valladolid 1983. 
de exponer para Fernando del Pulgar, frente a lo que puede observarse para Diego de Valera.

Tal como se anunciaba antes, la visión que Diego de Valera ofrece de la monarquía se fundamenta en una perspectiva jurídico-política, funcional y cortesano-nobiliaria ${ }^{32}$.

El rey debe adoptar una función de salvador para su reino, lo que implica que el reinar es más carga que gloria. Si éste es el planteamiento general del que parte Valera, lo que más le interesa destacar a lo largo de sus escritos es la relación entre el rey y la nobleza, pues entiende que tal aspecto constituye el punto clave para asegurar la eficacia de la política regia. Es indudable que la obsesión del autor por tal cuestión no debió de ser ajena al impacto que debieron de producirle los acontecimientos desarrollados con motivo de los conflictos que enfrentaron a Juan II y Enrique IV con parte de sus respectivas noblezas y de los que Valera fue testigo. Su trayectoria como hombre de armas al servicio de diversas familias nobles y afectado personalmente por las tensiones bélicas, en que se tradujo el conflicto nobleza-monarquía, tiene efectos directos sobre su producción intelectual ${ }^{33}$.

Consecuencia de esta trayectoria vital, en la que se mezcla el servicio como caballero en favor del rey o en favor de alguno de los más ilustres linajes, como el de los Estúñiga, colaborando con don Pedro de Estúñiga, o con el duque de Medinaceli ${ }^{34}$, será su preocupación por intentar conciliar los intereses de nobles y monarcas. Si el monarca debe ser considerado como el origen de todo ennoblecimiento ${ }^{35}$ y ha de tener un lugar principal en la resolución de los conflictos entre nobles ${ }^{36}$, la nobleza debe

\footnotetext{
32 Valera, Diego de, Tratado de las epístolas, ed. de Mario Penna, epístola I. Madrid 1959. 3 Sobre su trayectoria vital puede verse Rabadé ObRadó, María del Pilar, ob. cit., págs. 615623.

34 Véase con relación a la colaboración con este último SANCHO DE SOPRANis, Hipólito, "Sobre Mosén Diego de Valera. Notas y documentos para su biografía», Hispania, n. ${ }^{\circ}$ VII, 1947 , págs. 531-553.

35 "Nobleza es una calidad dada por el príncipe, por la qual alguno paresce ser más acepto allende los otros onestos plebeos». VALERA, Diego de, Espejo de verdadera nobleza, ed. de Mario Penna, cap. IV. Madrid 1959, págs. 92-93. Este planteamiento coincidía plenamente con el recogido en algunos documentos reales coetáneos en los que, con motivo de conceder el ennoblecimiento a alguien, se recordaba ese papel del rey como origen de sus nobles: "A los Reyes pertenesce en su real actoridad, y por la soberana dignidad suya ennoblecer y criar y facer nobles á las personas que son de virtud dotadas." Memorias de don Enrique IV de Castilla, II, doc. XLIX. Madrid 1913, pág. 141. En alguna ocasión, esta atribución del monarca se presenta como una plasmación más de su condición como vicario de Dios: «Esto porque el príncipe sólo puede dar las dignidades, así como aquel que tiene lugar de Dios en la tierra e no otro; el qual estas dignidades o noblezas tenporales instituye e da por la mano de aquel.» VALERA, Diego de, Espejo de verdadera nobleza, cap. IV, pág. 94.
}

${ }^{36}$ Tal función del rey en la solución de los conflictos entre nobles se pone de manifiesto 
contribuir a prestigiar a su rey, debiendo éste rodearse de los grandes señores del reino, otorgándoles el rey grandes distinciones y mercedes, pues tanto mayor gloria tendrá el rey cuanto más elevada distinción alcancen sus nobles ${ }^{37}$.

Como se ve, estamos ante la consecuencia natural de los compromisos políticos que el propio Diego de Valera hubo de compaginar durante toda su vida.

Hasta aquí se han puesto de relieve las posturas más personales de estos dos autores conversos, resultando bien patente la diversidad de planteamientos. Sin embargo, tal como se dijo, también hay un núcleo de pensamiento en el que se produce una coincidencia absoluta entre ambos.

Este núcleo coincidente presenta tres contenidos bien diferenciados:

1. Aquellos elementos del pensamiento político difundido durante el siglo XIII, muy vinculados a la teoría política de la escolásticas, que seguían teniendo plena vigencia a fines del siglo xv. Tales elementos estarán referidos preferentemente a la defensa del ideal del rey virtuoso ${ }^{38}$ y de la concepción corporativa del reino ${ }^{39}$, que, a fines del siglo $x v$, ha dejado de ser una teoría filosófica sólo conocida por pensadores con formación universitaria, para convertirse en un lugar común en la reflexión política ${ }^{40}$.

2. Aquellas concepciones que resultaban más expresivas de las tendencias autoritarias del momento, tal como sucedía con las repetidas alusiones al rey justiciero ${ }^{41}$, a la incuestionable superioridad regia ${ }^{42}$ en su reino y a la necesidad de una pompa regia como

en su destacada actuación en los retos y desafíos que tienen como escenario obligado la propia corte regia. A este respecto se pueden enccntrar amplias consideraciones por parte del propio Diego de Valera en su Tratado de las armas, ed. de Mario Penna. Madrid 1959.

37 Valera, Diego de, Exortación de la pas, ed. de Mario Penna. Madrid 1959, pág. 79.

${ }_{38}$ Ambos autores coinciden en que el ejercicio de la virtud en el sentido más puramente religioso de las virtudes teologales y cardinales, debe suponer un componente ideal en el modelo del rey ideal: Pulgar, Fernando del, Letras, letra IV y Glosas, glosa a la copla III; VARELA, Diego de, Exortación de la pas, pág. 82.

39 Sobre la importantísima presencia de la concepción corporativa en la obra de Diego de Valera y su reflejo, ya menos intenso en la de Fernando del Pulgar, véase Nieto SoRia, José Manuel, Fundamentos ideológicos, pág. 96.

${ }_{40}$ Sobre el origen de la concepción corporativa en Castilla puede verse MARAVALL, José Antonio, «Del régimen feudal al régimen corporativo en el pensamiento de Alfonso X», Estudios de Historia del pensamiento español, l. Madrid 1973, págs. 103-156.

41 Alusiones al rey justiciero en PULGaR, Fernando del, Letras, letra XVI; VALERA, Diego de, Tratado de las epístolas, epíst. I, pág. 4, Doctrinal de príncipes, ed. de Mario Penna, cap. III. Madrid 1959, pág. 187.

42 Sobre la superioridad del poder regio por encima de cualquier otro y, por tanto, sobre 
forma de comunicar esa posición de superioridad del monarca por encima de cualquier otra instancia de poder ${ }^{43}$.

3. Finalmente, la obsesiva reflexión sobre el problema del rey-tirano que tanto había impactado a la generación de Valera y de Pulgar, en cuanto qu ambos se habían tenido que definir ante las acusaciones de esta índole vertidas sobre un rey castellano como Enrique IV $^{44}$.

Así, por tanto, estos elementos coincidentes en sus escritos, no son tanto el resultado de una reflexión intelectual y personal, como la consecuencia, en unos casos, de unas corrientes de pensamiento de origen ya lejano y que se hallaban plenamente vigentes; en otros casos, de algunas de las realidades a través de las cuales tendía a manifestarse el propio poder regio, o, finalmente, en otras ocasiones, de la justificación de actitudes personales adoptadas a lo largo de la propia experiencia política personal.

Analizados estos dos autores, en los que se ha querido ver una cierta dimensión simbólica por su diversidad de perspectiva a pesar de la condición conversa que se da en ambos casos, partiendo, sin embargo, de un sustrato ideológico común, característico de la época en que les tocó vivir; se pasará a considerar otros escritores conversos, de significación sobre todo literaria, que, sin que tuvieran una preocupación específica por describir un modelo de realeza, manifestaron alguna opinión en sus escritos con relación a esta cuestión.

la preferencia del servicio al rey pueden verse PULGA.R, Fernando del, Letras, letras III y XVI; VALERA, Diego de, Tratado de las epístolas, epíst. I, pág. 3, este texto de Valera resulta sumamente interesante en cuanto que vincula la idea de unidad del reino a la de soberanía y a la de superioridad del poder regio.

${ }_{43}$ Ambos autores fueron conscientes de la importancia que para el fortalecimiento del poder regio podía tener la adecuada utilización de unos procedimientos de exhibición del monarca. Si Pulgar expresa cómo la realeza debe rodearse de una pompa que ponga claramente de manifiesto su superioridad frente a los demás poderes del reino (véase Claros varones de Castilla, edic. cit., pág. 152), Diego de Valera siempre estará especialmente atento a describir en sus relatos cronísticos los acontecimientos solemnes que tienen lugar en torno a los monarcas, tal como puede verse, por ejemplo, en Memorial de diversas hazañas, caps. I y LII.

${ }_{44}$ Sobre la unilateral postura de Fernando del Pulgar sobre el problema de los reyes tiranos, negando cualquier posibilidad de resistencia por parte de los súbditos, así como sobre la cambiante posición de Valera, favorable primero a la deposición del tirano y negando tal recurso ya en tiempos de los Reyes Católicos, así como el contexto ideológico que se produce sobre este problema en la Castilla bajomedieval puede verse NIETo SoRIA, José Manuel, Fundamentos ideológicos, págs. 183-193. 


\section{LA EXALTACIÓN LITERARIA DE LA REALEZA CASTELLANA EN ALGUNOS ESCRITORES CONVERSOS}

Los escritores conversos, ya más arriba citados, fray Diego de Valencia, Juan Alfonso de Baena, Gonzalo Martínez de Medina, fray Íñigo de Mendoza, Antón de Montoro y Juan de Lucena, presentan una fórmula de acercamiento común a una descripción del poder monárquico. Esta fórmula viene definida por la apología, tanto de indole personal, dirigida a un monarca concreto, como de índole institucional, dirigida a la institución monárquica en su conjunto.

Por lo que se refiere a los aspectos concretos en que suelen fijar su atención, también se puede advertir alguna nota común, perfectamente coherente con lo que eran los ideales políticos monárquicos de la época. Por un lado, la referencia a la superioridad regia, acorde con las tendencias autoritarias, y, por otro lado, la referencia a la consideración del rey como monarca cristianísimo o virtuoso, acorde con una tradición política cuya aceptación se había reforzado considerablemente en todo el occidente a fines del medievo.

En efecto, la superioridad regia se plasmaba a través de diversas expresiones de exaltación muy frecuentes, sobre todo en los textos poéticos de los cancioneros ${ }^{45}$, y que parecían reproducir las fórmulas cancillerescas habitualmente utilizadas por la propia Cancillería real.

Fray Diego de Valencia alude a Juan II como sujeto de reverencia para sus vecinos por ser aquél del "alto nombre" ${ }^{46}$. Juan Alfonso de Baena preferirá hablar de «muy soberano» y «alto rey» ${ }^{47}$. Gonzalo Martínez de Medina exaltará la persona del rey, presentándola como un noble pero de calidad muy superior a cualquier noble del reino ${ }^{48}$. Fray Íñigo de Mendoza será uno de los que más abunde en esta faceta de la realeza, poniendo de manifiesto que los reyes están «tan sobidos que son de todos temidos» ${ }^{49}$, y utilizando fórmulas alusivas a los monarcas castellanos tales

45 En cuanto que frecuentemente se hará alusión a algunas ediciones de cancioneros, cuando se indique en una nota Cancionero de Juan Alfonso de Baena, se estará aludiendo a AzACETA, J. M., Cancionero de Juan Alfonso de Baena, 3 vols. Madrid 1966. Y cuando se hable en nota de Cancionero castellano, se aludirá a Foulché-Delbosc, R., Cancionero castellano del siglo XV, 2 vols. Madrid 1912-1915.

46 Valencia, Diego de, Cancionero de Juan Alfonso de Baena, compos. 227, versos 133135.

47. Cancionero de Juan Alfonso de Baena, apéndice III, pág. 1159, versos 3-4.

48 Cancionero de Juan Alfonso de Baena, compos. 335, versos 1-4.

49 Mendoza, Fray Íñigo de, Cancionero, ed. de Julio Rodríguez Puértolas, estrofa 18. Madrid 1968, pág. 288. 
como «príncipe soberano», «real alteza», «príncipe muy poderoso» " rey» ${ }^{51}$, "alta reina esclarecida» ${ }^{52}$, "reina soberana» ${ }^{53}$, o "príncipe muy soberano» ${ }^{54}$. Finalmente, Antón de Montoro se referirá a Isabel la Católica como «alta reina soberana» ${ }^{55}$.

Si esta coincidente valoración del rey como instancia de poder superior representa algo que, desde el punto de vista de la evolución de la ideología política, podría valorarse como anuncio de cierta modernidad; en cambio, la también coincidente presentación del monarca entre nuestros autores conversos como un rey cristianísimo y virtuoso responde a la preferencia que en los tiempos medievales se tuvo por un rey como símbolo de un comportamiento ético frente a otro modelo regio, el renacentista, en el que prima más un enfoque en el que lo virtuoso se asimila a lo que, en cada momento, es políticamente conveniente.

Para fray Diego de Valencia, Juan II fue leal a Dios, católico firme y defensor de la ley de Cristo ${ }^{56}$. También Gonzalo Martínez de Medina acudirá a la enumeración de virtudes como forma de exaltar a este mismo monarca ${ }^{57}$. Fray Íñigo de Mendoza preferirá ceñirse a la enumeración de las virtudes teologales y cardinales ${ }^{58}$. Antón de Montoro, aunque sin ocultar un cierto deje irónico, equiparará por sus virtudes a Isabel I con la propia Virgen María ${ }^{59}$.

Si hasta aquí se ha considerado lo que son las dos bases comunes más generalizadas entre los escritores conversos señalados, en su descripción del rey y del poder regio, conviene ahora establecer los matices diferenciales en cada caso individual.

Fray Diego de Valencia ha ofrecido dudas sobre su carácter de judeoconverso. Franciscano y maestro en Teología desde 1407 debería ser considerado, a no dudar, como tal converso, para unos autores ${ }^{60}$; mientras que, para otros, es incuestionable que presenta un importante nivel

50 Ibidem, pág. 229 , estrofa 1 y pág. 300 , estrofas 4 y 5 .

Ibidem, pág. 317, estrofa 52

Ibidem, pág. 281, estrofa 1.

Ibidem, pág. 293, estrofa 30.

4 MENDOZA, Fray Íńigo de, "Sermón trobado», en Cancionero castellano, pág. 52.

5 Cancionero de Antón de Montoro, ed. de E. Cotarelo y Mori, n. ${ }^{\circ} 35$. Madrid 1900.

Cancionero de Juan Alfonso de Baena, compos. 227, versos 121-128.

57 Cancionero de Juan Alfonso de Baena, compos. 335, versos 9-16.

58 Mendoza, Fray Ínigo de, Cancionero, pág. 343, estrofas 78-80.

59 Véase nota 54.

50 Véase SOLE-SOLE, J. M. y Rose, S. E., "Judíos y conversos en la poesía cortesana del siglo xv: el estilo polígloto de fray Diego de Valencia», Hispanic Review, n. ${ }^{\circ} 44,1976$, págs. 271 285. 
de información sobre lengua y cultura hebraicas que quizá, en parte, se podría relacionar con su nacimiento en Valencia de don Juan, donde existía una importante judería, pero que, en cualquier caso, dejaría abierta la puerta a su posible origen judaico ${ }^{61}$.

Los aspectos más distintivos de este autor en sus referencias poéticas a la monarquía encarnada por Juan II se referirán, sobre todo, a las alusiones a la descripción del rey desde la perspectiva de los ideales caballerescos ${ }^{62}$, de su actuación como protector de la Iglesia, coherente con su condición de eclesiástico y sobre todo de miembro de la orden franciscana, tan favorecida por este monarca ${ }^{63}$, y de sus obligaciones como rey justiciero, sin olvidar referirse en algún momento a su carácter como vicario de Dios.

Juan Alfonso de Baena ${ }^{64}$, en cambio, apenas representa otras aportaciones en esta materia que las ya reseñadas antes de la perspectiva de la exaltación de la superioridad regia.

Gonzalo Martínez de Medina no ofrece dudas sobre su condición conversa, siendo hijo del tesorero mayor de Andalucía, Diego Martínez de Medina ${ }^{65}$. Su proximidad a los medios cortesanos hizo que conociese bien el entorno regio, estando muy presente en su obra la crítica antinobiliaria, pero sin que, en cambio, falten las expresiones apologéticas en favor del poder regio frente a! poder de la nobleza, doliéndose de la necesidad de que el monarca deba recurrir a otorgar continuas prebendas a los nobles a fin de asegurarse su fidelidad ${ }^{66}$. Un aspecto peculiar de su apología a la realeza será el presentar a Juan II en una dimensión celestial e inmortal ${ }^{67}$.

Fray Íñigo de Mendoza, procedente por vía materna de la familia de los Cartagena, conversos burgaleses ${ }^{68}$, también representa otro caso en

61 Cantera Burgos, Francisco, «El cancionero de Baena: judíos y conversos en él», Sefarad, n. ${ }^{\circ}$ XXVII, 1967, 71-111, sobre fray Diego de Valencia, el que incluye entre los posibles autores conversos del cancionero, pueden verse las págs. 97-103.

62 Cancionero de Juan Alfonso de Baena, compos. 227, versos 122-125.

63 A este respecto puede verse NIETO SORIA, José Manuel, «Franciscanos y franciscanismo en la política y en la corte de la Castilla Trastámara", Anuario de Estudio Medievales, $\mathrm{n} .^{\circ} 20$, 1990, págs. 109-131.

${ }_{64}$ Sobre su posible origen converso pueden verse AVALLE-ARCE, J. B., "Sobre Juan Alfonso de Baena», Revista de Filología Hispánica, n. ${ }^{\circ}$ VIII, 1946, págs. 141-147 y la introducción de AzACETA, J. M., ob. cit., vol. l, págs. VI-VII, en donde se defiende su origen converso.

65 FRAKER, Ch. F., "Gonçalo Martínez de Medina, the Jerónimos and the Devotio Moderna», Hispanic Review, n. ${ }^{\circ}$ XXXIV, 1966, págs. 197-217.

66 Cancionero de Juan Alfonso de Baena, compos. 335, pág. 742, versos 73-80.

67 loidem, versos 85-88.

68 Datos biográficos sobre este autor en Rodríguez Puertolas, Julio, Fray íñigo de Mendoza 
el que se produce un estrecho contacto con los medios cortesanos, dándose incluso una situación de servicio directo a los monarcas, como consecuencia de haber sido predicador y limosnero de la reina Isabel. De todos los poetas conversos va a ser el más interesado por reflejar en su obra su percepción personal de la realeza y del poder regio, dando la impresión de que su postura no es tanto, como en otros casos, la simple búsqueda de unas expresiones con relieve literario que pongan de manifiesto una actitud apologética, sin mayor profundidad, sino también un intento de manifestar un ideal monárquico personalmente asumido y plenamente acorde con las tendencias de la época.

Para Íñigo de Mendoza, el origen divino del rey y de la realeza sigue siendo argumento básico esencial en la caracterización de estas instituciones, empleando, para expresar la importancia de tal creencia, un término bien gráfico, al calificarla como de "ley sacramento» ${ }^{69}$. Por otra parte, la concepción monárquica de fray íñigo de Mendoza está cargada del fuerte mesianismo imperante en la Castilla de fines del siglo xV, lo que da lugar a la alusión a los monarcas castellanos como reyes ungidos $^{70}$ y como reyes-mesias ${ }^{71}$, haciéndolos objeto de grandes augurios proféticos relativos a los efectos benéficos de su gestión política y a las metas que habrán de alcanzar como enviados de Dios para la realización de grandes empresas ${ }^{72}$

Finalmente, la otra dimensión de sus concepciones monárquicas, tal como son expresadas en sus versos, es la que refleja de una manera más directa lo que son las tendencias autoritarias hacia las que va la institución monárquica, exaltándose la función justiciera de ésta ${ }^{73}$, sus atribuciones legislativas ${ }^{74}$ o su posición de dominio sobre el estamento nobiliario ${ }^{75}$.

y sus "Coplas de Vita Christi”. Madrid 1968 y del mismo autor, Fray Ínigo de Mendoza. Cancionero. Madrid 1968.

69 Mendoza, Fray ínigo de, Cancionero, pág. 321, estrofa 10.

70 Mendoza, Fray ínigo de, Cancionero, pág. 322, estrofas 11 y 12 y Cancionero castellano, págs. 64,70 y 71 .

71 Mendoza, Fray Íñigo de, Cancionero, pág. 281, estrofa 1

72 Ibidem, págs. 317-318, estrofa 53 y pág. 330 , estrofas 35 y 36 .

73 Para Fray Íñigo de Mendoza, la salvaguarda de la justicia y de la libertad en el reino sólo puede venir plenamente garantizada por la adecuada acción justiciera de los monarcas. Cancionero, págs. 305 , estrofa 18. En consecuencia, no se debe consentir que por la falta de justicia el reino se envilezca, no debiendo dudar los reyes de aplicar la pena de muerte a quien ponga en peligro el bienestar del país. Ibidem, pág. 285, estrofa 11 y pág. 313 , estrofa 39.

74 Una alusión a la función legislativa de los monarcas en lbidem, pág. 344, estrofa 81.

75 Esta posición de dominio de los monarcas sobre los nobles debe tener su debida contrapartida, estando los reyes obligados a comprar la fidelidad de aquéllos, pues, de lo contrario, puede sobrevenir el enfrentamiento armado. Cancionero castellano, I, pág. 55 . En este punto, 
Mucha menor atención manifiesta Antón de Montoro hacia el tipo de cuestiones que aquí interesa considerar. No obstante, la casi divinización que Montoro aplica a la reina Isabel ${ }^{76}$, supone un grado de extrema apología de esta reina, probablemente no alcanzado por ningún otro poeta de la época ${ }^{77}$.

Juan de Lucena, finalmente, representa un caso aparte de los autores que acaban de tratarse ${ }^{78}$, en cuanto que no es un poeta y su obra no nace de un intento de exaltación poética, sino de una pretensión reflexi$v^{79}$. Sin embargo, a pesar de esta pretensión reflexiva, los efectos de apología y casi sublimación del monarca, en este caso Juan II, alcanzan cotas equivalentes a los casos anteriores, aludiendo a éste como «el sancto rey nuestro don Juan» ${ }^{80}$.

\section{PABLO Y ALFONSO DE SANTA MARIA Y LA PERCEPCIÓN HISTÓRICA DE UN NUEVO MODELO MONÁRQUICO}

La obra historiográfica de Pablo de Santa María y Alfonso de Cartagena ha sido objeto de consideración por diversos autores. No parece, por tanto, que sea éste el momento de volver sobre ello ${ }^{81}$.

Baste en esta ocasión con señalar que dicha obra historiográfica supuso el dotar al pensamiento político castellano, en su esfuerzo por es-

Fray Íñigo de Mendoza se muestra plenamente solidario con la óptica propia de los miembros de los grandes linajes cortesanos, tales como el de los Mendoza, de donde él procede.

${ }_{76}$ Cancionero de Antón de Montoro, $n .{ }^{\circ} 35$.

77 Conviene reproducir aquí el comentario que Alan Deyermond expresa con relación al significado que este autor atribuye al poema a la reina Isabel de Antón de Montoro: «Parece que en esta poesía Montoro se acerca al concepto del monarca cuasi-divino, y que anuncia el estado moderno en una forma nueva y amer azadora, la monarquía absoluta." DEYERMOND, Alan, "La ideología del Estado moderno en la literatura española del siglo XV", pág. 193.

78 Un pormenorizado estudio biográfico sobre este autor puede encontrarse en ALCALÁ, Ángel, «Juan de Lucena y el preerasmismo españo|», Revista Hispánica Moderna, n. ${ }^{\circ} 34,1968$, págs. 108-131.

79 Sobre la obra de este autor puede verse LóPEz CONDE, Juan Carlos, «El siglo xv castellano a la luz del Diálogo de Vita Beata de Juan de Lucena", Dicenda. Cuadernos de Filologia Hispánica, $n^{\circ} 4,1985$, págs. 11-34.

${ }_{80}$ LuCENA, Juan de, Tratado de vita beata. Burgos 1502; pág. 8.

81 Entre los diversos estudios publicados sobre estos autores pueden verse CANTERA BurGos, Francisco, Alvar García de Santa María. Historia de la Judería de Burgos y de sus conversos más egregios. Madrid 1952; Ios trabajos contenidos sobre su obra historiográfica en TATE, Robert B., Ensayos sobre la Historiografia peninsular del siglo xv. Madrid 1970, y los estudios más recientes de DeYermond, Alan, «Historia universal e ideología nacional en Pablo de Santa María», Homenaje a Alvaro Galmés de Fuentes, II. Madrid 1985, págs. 313-324 y SconzA, Jean, "A Reevaluation of the Siete Edades del Mundo", La Corónica, n. ${ }^{\circ} 16,1987-1988$, págs. 94-112. 
tablecer elementos de reflexión sobre el sentido y significado de la realeza castellana, de todo un conjunto de referencias que contribuían a justificar, desde una perspectiva histórica y bíblica, las pretensiones de mayor protección política de esa monarquía.

Teniendo en cuenta el sentido que fueron tomando las reflexiones de los intelectuales de fines del siglo xv sobre la significación de la monarquía castellana, hay que pensar en la posibilidad de la importante influencia que la obra de estos autores conversos pudo tener en ese proceso de reflexión.

$\mathrm{Si}$ es posible hallar unos fundamentos nítidos del milenarismo y del mesianismo aplicados a las concepciones de la realeza que se muestran de forma tan características a fines del siglo XV, éstos pueden encontrarse con toda facilidad en Las siete edades del mundo, de Pablo de Santa María. Del mismo modo que la Anacephaleosis, de Alfonso de Cartagena, aporta elementos decisivos en orden a dotar a la monarquía castellana de un basamento ideológico respaldado por una trayectoria histórica difícilmente parangonable en todo el mundo occidental.

Por otra parte, es necesario tener en cuenta la amplia difusión que en los medios intelectuales debió de tener la obra de estos autores, difusión además favorecida por la actividad intelectual desarrollada por algunos de sus más destacados discípulos, tales como un Rodrigo Sánchez de Arévalo o un Alfonso de Palencia ${ }^{82}$.

Sin embargo, las aportaciones de estos autores no deben valorarse desde la perspectiva de considerarlas como posible justificación de lo que podría entenderse como una influencia intelectual concentrada en el ámbito exclusivo de los intelectuales conversos. Nada de esto parece probable que sucediera. Por lo que parece más plausible pensar que tal influencia, que, desde luego, debió de producirse, contribuiría a establecer algunos lugares comunes aprovechables por cualquiera interesado en consolidar las pretensiones centralizadoras de la monarquía castellana de fines del medievo, independientemente de su carácter de converso o de cristiano viejo.

\section{CONCLUSIONES}

A partir de los datos aquí manejados, no parece posible hablar de una imagen específicamente conversa de la realeza castellana. Ésta es objeto $42-44$

82 Véase NADER, Helen, Los Mendoza y el renacimiento español. Guadalajara 1986, págs. 
de representación por cada intelectual converso en función de un ambiente cultural e ideológico general, así como de su propia experiencia política personal, siendo el resultado de tales circunstancias una imagen en la que, junto con una serie de lugares comunes, propios de las representaciones políticas predominantes en la época, aparecen otras inquietudes individuales.

Después del análisis realizado, parece factible establecer lo que podrían considerarse como los elementos constitutivos básicos que incidieron en la elaboración de un cierto concepto de monarquía observable en los autores estudiados, sin que tal concepto, como se acaba de señalar, represente una posición original frente a otros autores coetáneos no conversos.

Dichos elementos constitutivos serían, sobre todo, los siguientes:

1. La presencia de una preocupación muy difundida por establecer elementos de reflexión intelectual sobre el nuevo sentido que parecía que iba tomando la institución monárquica.

2. El pensamiento teológico-político orgánicamente expresado a partir del siglo XIII y ampliamente difundido durante el siglo XV.

3. La incidencia de los textos bíblicos, sobre todo los veterotestamentarios.

4. Las expresiones de las tendencias autoritarias que pretende desarrollar la monarquía en su proceso de configuración de una solución estatal y que, en muchos casos, suponen una versión literaria de las fórmulas cancillerescas entonces vigentes.

5. La visión histórica de una monarquía castellana a la que se suele atribuir una proyección hispánica, visión histórica elaborada a partir de los criterios propios de la construcción de los denominados «falsos", caracterizados por dar legitimidad a partir de una supuesta antigüedad, casi siempre imaginada.

6. Las propias experiencias individuales de índole política, resultantes, sobre todo, de dos circunstancias determinantes: la vinculación con los medios cortesanos y con los propios monarcas y la actitud personal en el conflicto nobleza-monarquía que, en algunos casos, provocará una necesidad de justificación.

De entre todos estos elementos, es el último el que contribuye a dar un matiz personal frente al sustrato común determinado por todos los demás.

Sin embargo, hay que reconocer un destacado protagonismo por parte de los intelectuales conversos a la hora de hacer un esfuerzo dirigido a 
expresar una cierta concepción de la realeza castellana como institución y como instancia de poder. Tal hecho debe ser explicado.

Esta explicación no puede ser ajena a las propias circunstancias vitales de estos individuos, cuya supervivencia, en unos casos, o cuya posición social en otros, amenazadas ocasionalmente, debieron hacerles particularmente sensibles al devenir histórico de la época. En ese mismo contexto, la monarquía se constituyó en la principal referencia en el intento de racionalización de unas condiciones vitales que ofrecían momentos de adversidad, lo que unido a las propias tendencias políticas de la época, enmarcadas en el proceso de génesis del Estado Moderno, contribuiría a que algunos de estos intelectuales se convirtieran en fieles transcriptores de lo que eran las nuevas pretensiones - casi realidades al término del siglo $x v$ - del poder regio en la Castilla de fines del medievo y en los albores de la llamada Monarquía Católica Hispánica de los tiempos modernos. 